\title{
PENGEMBANGAN BUKU TEKS BAHASA INDONESIA KELAS VI SD BERBASIS KARAKTER DENGAN MENGGUNAKAN MODEL PEMBELAJARAN EXAMPLE NON-EXAMPLE
}

\author{
Endah Wening Subekti ${ }^{1}$, Bambang Yulianto ${ }^{2}$, Wahyu Sukartiningsih ${ }^{3}$ \\ Pendidikan Dasar, Pascasarjana Universitas Negeri Surabaya \\ email: endahwenings@gmail.com
}

\begin{abstract}
Abstrak
Tujuan umum penelitian ini adalah mengembangkan buku teks Bahasa Indonesia kelas VI berbsasis karakter dengan menggunakan model pembelajaran example non example. Adapun tujuan khusus penelitian ini adalah: (1)mendeskripsikan proses pengembangan buku teks bahasa Indonesia kelas VI berbasis karakter dengan menggunakan model pembelajaran example non example (2)mendeskripsikan kualitas buku teks bahasa Indonesia kelas VI berbasis karakter dengan menggunakan model pembelajaran example non example yang dikembangkan.Penelitian ini termasuk jenis penelitian pengembangan dengan pendekatan kombinasi kualitatif kuantitatif model sequential exploratory dan desain model merupakan adaptasi dari model 4D. Prosedur pengembangan meliputi tahap pendefinisian, perancangan, dan pengembangan. Hasil penelitian menunjukkan bahwa proses pengembangan meliputi tahap pendefinisian dengan hasil berupa peta kebutuhan pembelajaran; tahap perancangan dengan hasil draf buku; dan tahap pengembangan dengan hasil berupa model final buku teks. Kualitas buku teks yang dikembangkan dinilai dari komponen materi, penyajian, bahasa, dan kegrafikaan. Masing-masing komponen mendapat persentase 97,9\%, 100\%, 96,4\%, 93,8\%. Pemerolehan hasil observasi di kelas VIA terhadap aktivitas guru, respon guru, aktivitas siswa, dan respon siswa berturut-turut $87,5 \%, 86,1 \%$, $84,4 \%, 90,7$, serta hasil belajar siswa mengalami peningkatan sebesar 9,5. Pemerolehan hasil observasi di kelas VIC terhadap aktivitas guru, respon guru, aktivitas siswa, dan respon siswa berturut-turut $95,8 \%, 97,1 \%, 81,3 \%$, 90,3 , serta hasil belajar siswa mengalami peningkatan sebesar 8,6.
\end{abstract}

Kata Kunci: Pengembangan Buku Teks, Karakter, Model Pembelajaran Example Non-Example

\section{Abstract}

The general objective of this research was to develop Indonesian language textbooks for VI grade based on characters using example non-example learning models. The specific objectives of this study were: (1)describe the development process of Indonesian language textbooks for VI grade based on characters using example nonexample learning models. (2)describe the quality of Indonesian language textbooks for $V^{h}$ grade based on characters using example non-example learning model developed. This study is kind of development research with a quantitative qualitative combination approach of sequential exploratory model and the design model is an adaptation of the $4 D$ model. The development procedure includes the step of defining, designing, and developing. The results showed that the development process are includes: the defining step result is learning needs map; the designing step result is the books draft; and the developing step results is the final model of the textbook. The quality of the developed textbooks assessed from materials component, presentation, language, and charts. Each component gets a percentage of $97.9 \%, 100 \%, 96.4 \%$, and $93.8 \%$. The observation results of the VI grade A-class teacher's activities, teacher's response, student activities, and student responses are respectively $87.5 \%, 86.1 \%, 84.4 \%, 90.7$, and the learning outcomes of students has increased by 9,5. The observation results of the VI grade C-class teacher's activities, teacher's response, student activities, and student responses are respectively $95.8 \%, 97.1 \%, 81.3 \%, 90.3$, and the learning outcomes of students has increased by 8,6 .

Keywords: Textbook Development, Character, Example Non-Example Learning Model

\section{PENDAHULUAN}

Peraturan Menteri Pendidikan Nasional Nomor 2 Tahun 2008 bab V yaitu "buku teks digunakan sebagai acuan wajib oleh pendidik dan peserta didik dalam proses pembelajaran" (http://luk.staff.ugm.ac.id). Buku teks yang digunakan harus diperhatikan mutu dan cakupan isinya, dalam hal ini Peraturan Menteri Pendidikan
Nasional No 2 Tahun 2008 bab IV menjelaskan bahwa satuan pendidikan berhak memilih buku teks yang tersedia di pasar melalui rapat pendidik apabila menteri pendidikan belum menetapkan kelayakan pakai buku teks pelajaran (http://luk.staff.ugm.ac.id). Peraturan tersebut memberikan solusi pemecahan masalah pemakaian buku teks dengan tetap 
mengutamakan mutu buku teks melalui rapat pendidik.

Kurikulum yang digunakan pada saat ini terutama di kota Surabaya adalah Kurikulum 2013. Kurikulum 2013 melebur beberapa mata pelajaran ke dalam mata pelajaran lain. Di kelas VI belum menggunakan Kurikulum 2013, oleh karena itu penelitian pengembangan ini tetap perlu mempertimbangkan Kurikulum 2013, sehingga produk yang dihasilkan memiliki masa kegunaan yang lebih panjang. Buku teks yang dihasilkan menyesuaikan dengan karakteristik perkembangan siswa kelas VI, karakter yang diintegrasikan, dan mempertimbangkan draf Kurikulum 2013.

Peraturan Pemerintah Nomor 19 Tahun 2005 tentang Standar Nasional Pendidikan Pasal 26 Nomor 1 menjelaskan bahwa "standar kompetensi lulusan pada jenjang pendidikan dasar bertujuan untuk meletakan dasar kecerdasan, pengetahuan, kepribadian, akhlak mulia, serta keterampilan untuk hidup mandiri dan mengikuti pendidikan lebih lanjut" (http://kemenag.go.id). Berdasarkan permendiknas tersebut penelitian pengembangan ini memilih kelas VI. Tujuan pemilihan kelas VI sebagai subjek penelitian pengembangan adalah untuk memperkuat karakter siswa yang ditanamkan dari kelas I-V, sehingga tujuan meletakan kepribadian dan ahlak mulia yang ada di standar kompetensi lulusan dapat tercapai.

Berdasarkan observasi awal yang dilaksanakan di SDN Ketintang 1/409 Surabaya khususnya kelas VI pada tanggal 1 September 2014 serta berdasarkan hasil wawancara dengan guru kelas VI di sekolah tersebut, dikatakan bahwa bahan ajar yang digunakan adalah buku sekolah elektronik (bse) dan kurang menekankan karakter sehingga nilai-nilai tersebut hanya disampaikan secara lisan atau hanya sebatas pesan-pesan moral berdasarkan kemampuan guru tersebut. Siswa hanya menggunakan buku bse sebagai sumber belajar sehingga menyebabkan hasil ketercapaian tujuan pembelajaran belum optimal, dimana nilai rata-rata ulangan harian pada mata pelajaran bahasa Indonesia belum bisa mencapai Kriteria Ketuntasan Minimal (KKM) yaitu $\geq 70$.

Aktivitas siswa dalam pembelajaran juga masih pasif. Salah satu penyebab pasifnya siswa dalam pembelajaran adalah kurangnya buku teks yang digunakan dalam pembelajaran bahasa Indonsia di kelas. Oleh karena itu, diperlukan buku teks lain untuk memperluas wawasan. Dengan wawasan yang luas siswa dapat berinteraksi dengan baik dalam belajar.
Strategi yang digunakan dalam konteks Kurikulum 2013 dalam implementasinya harus diwadahi oleh pembelajaran kooperatif. Hal ini berarti pendekatan apapun yang digunakan haruslah dipadukan dengan pembelajaran kooperatif sehingga siswa akan terbina kemampuan kolaborasi dan komunikasinya selama proses pembelajaran.

Pada pembelajaran kooperatif terdapat beberapa model yang bisa membantu proses belajar siswa. Model pembelajaran yang memudahkan siswa dalam pembelajaran bahasa Indonesia yaitu model pembelajaran example non-example. Model pembelajaran ini belum pernah digunakan pada proses pembelajaran di kelas VI SDN Ketintang 1/409 Surabaya. Model ini menggunakan gambar sebagai media pembelajaran. Gambar tersebut bisa disajikan melalui Over Head Projector (OHP), LCD, poster maupun media penampil gambar lainnya. Model pembelajaran example non example didasarkan atas contoh. Contoh dapat diambil dari kasus atau gambar yang relevan dengan kompetensi dasar (Aqib, 2013:17). Menurut Cohen, Manion, dan Morrison (2011:530), gambar bisa berasal dari guru, atau hasil gambar dari siswa.

Berdasarkan kenyataan permasalahan dalam buku teks tersebut, maka penelitian ini bertujuan untuk mengembangkan buku teks yang dapat menjawab permasalahan tersebut yaitu dengan mengembangkan buku teks bahasa Indonesia kelas VI berbasis karakter dengan menggunakan model pembelajaran example non-example yang diharapkan dapat mengembangkan nilai karakter siswa dan meningkatkan aktivitas serta hasil belajar siswa.

\section{METODE}

Ditinjau dari aspek tujuan, penelitian ini merupakan penelitian pengembangan. Penelitian pengembangan merupakan strategi atau metode yang ampuh untuk memperbaiki praktik. Penelitian ini merupakan suatu proses atau langkah-langkah untuk mengembangkan produk baru atau untuk menyempurnakan produk-produk yang telah ada yang dapat dipertanggungjawabkan (Sukmadinata, 2005:164). Pendekatan yang digunakan yaitu kombinasi kualitatif-kuantitatif model sequential exploratory. Model sequential exploratory adalah metode penelitian kombinasi yang menggabungkan metode penelitian kualitatif dan kuantitatif (Sugiyono, 2013:415). Desain penelitian ini mengacu Four-D Model. Model pengembangan ini terdiri atas empat tahap pengembangan yaitu pendefinisian (define), perancangan (design), 
pengembangan (develop) dan penyebaran (disseminate) (Thiagarajan dalam Trianto, 2007:65). Dalam penelitian ini pengembangan buku teks diadaptasi hanya sampai pada tahap pengembangan, sehingga buku teks yang telah dikembangkan hanya digunakan pada sekolah uji coba, tanpa disebarkan pada sekolah lain.

Tahap pendefinisian bertujuan untuk menetapkan dan mendefinisikan syarat-syarat pembuatan buku teks. Ada lima langkah pokok dalam tahap pendefinisian. Tahap tersebut yaitu analisis awal akhir, analisis siswa, analisis konsep, analisis tugas, dan analisis tujuan pembelajaran.

Pada tahap perancangan, buku teks ini disusun dan ditulis sesuai dengan syarat dari BSNP 2007 yaitu memperhatikan kelayakan isi, kelayakan bahasa, kelayakan penyajian, dan kelayakan kegrafikaan. Buku teks yang telah ditulis dan disusun merupakan draf I buku teks berbasis karakter. Proses selanjutnya buku teks draf I diberikan pada tim validator untuk diuji kelayakannya. Penilaian, masukan dan saran dari validator digunakan untuk merevisi draf I. Berdasarkan masukan dari validator draf awal buku teks hasil pengembangan direvisi. Hasil revisi ini disebut dengan draf II. Draf II diberikan kembali pada tim validator untuk diberikan penilaian. Hasil revisi pada draf II disebut dengan draf III. Kegiatan dilanjutkan dengan uji terbatas draf III dan uji coba luas.

Data dalam penelitian ini yaitu, (1) data proses pengembangan merupakan data dari hasil tahap pendefinisian (define) dan tahap perancangan (design). Data hasil tahap pendefinisian yaitu berupa rumusan KI dan KD. Data hasil tahap perancangan berupa penilaian dari tim validator untuk draf I buku teks. Data hasil tahap pengembangan berupa penilaian dari tim validator untuk draf II dan data penilaian buku dari sudut pandang guru dan siswa, (2) data kualitas buku teks dari hasil tahap pengembangan (develop) yaitu skor nilai dari validator dan calon pengguna yang dirinci sebagai berikut (a) skor nilai hasil validasi draf II buku teks untuk kelayakan materi, bahasa, penyajian dan kegrafikaan digunakan sebagai data untuk menjawab masalah kualitas buku teks dari segi produk (b) Skor nilai dari data analisis guru, analisis siswa dan hasil belajar siswa baik dari uji coba terbatas maupun uji coba luas sebagai data untuk kualitas buku teks dari segi penggunaan

Sumber data pada penelitian ini yaitu, (1) sumber data dari proses pengembangan (develop) yaitu standar isi pada Kurikulum 2013 (2) sumber data dari penilaian kualitas buku teks terdiri dari 78 responden dengan rincian yaitu, validator aspek materi dan validator bahasa terdiri dari 1 orang, validator aspek penyajian terdiri dari 1 orang, validator kegrafikaan terdiri atas 1 orang, calon pengguna buku teks yang terdiri dari 13 orang, yaitu 1 guru dan 12 siswa kelas VI SDN Ketintang 1/409 Surabaya yang dijadikan responden dalam uji coba terbatas, dan Pengguna buku teks yang terdiri atas 60 siswa dan 2 guru kelas VI SDN Ketintang 1/409 Surabaya yang dijadikan responden dalam uji coba luas.

Teknik pengumpulan data yang digunakan dalam penelitian ini adalah dokumentasi, validasi, observasi, angket dan tes hasil belajar siswa. Instrumen penelitian yang akan digunakan dalam penelitian ini adalah lembar pemetaan KI, KD dan indikator-indikator; lembar pemerolehan bahan ajar; lembar validasi buku teks untuk materi; lembar validasi buku teks untuk penyajian; lembar validasi buku teks untuk kebahasaan,; lembar validasi buku teks untuk kegrafikan; lembar observasi terhadap aktivitas guru selama penggunaan draf buku teks; lembar angket terhadap respons penggunaan buku oleh guru; lembar observasi terhadap aktivitas siswa selama penggunaan draf buku teks; lembar hasil belajar siswa terhadap pencapaian tujuan pembelajaran; dan lembar angket terhadap respons penggunaan buku oleh siswa.

Sedangkan teknik penganalisisan data yang digunakan dalam penelitian pengembangan ini adalah kombinasi deskriptif kualitatif-kuantitatif. Skala yang digunakan untuk penilaian buku teks dari validator adalah skala Likert dengan gradasi jawaban mulai dari positif sampai negatif (Sugiyono, 2008:93).

Tabel 1. Kriteria Interpretasi Skor

\begin{tabular}{|c|c|}
\hline Skor & Keterangan \\
\hline 4 & Sangat Baik \\
\hline 3 & Baik \\
\hline 2 & Kurang Baik \\
\hline 1 & Tidak Baik \\
\hline
\end{tabular}

Pengolahan data dari hasil validasi menggunakan rumus:

$$
\mathrm{P}(\%)=\frac{\text { Skor yang diperoleh }}{\text { Skor maksimal }} \times 100 \%
$$

(Arikunto, 2006:40)

Untuk mengetahui kelayakan pada tiap komponen, skor yang diperoleh diubah menjadi persentase dengan skala $0 \%$ - 100\%. Interval persentase yang digunakan sebagai berikut: 
1) $85 \%$ - $100 \%$ dengan kriteria sangat layak

2) $75 \%$ - $84 \%$ dengan kriteria layak

3) $60 \%-74 \%$ dengan kriteria cukup layak

4) $40 \%-59 \%$ dengan kriteria tidak layak

5) $0 \%$ - 39\% dengan kriteria sangat tidak layak

Pengolahan data dari aktivitas guru dan siswa menggunakan rumus:

$$
\mathrm{P}(\%)=\frac{\text { skor yang diperoleh }}{\text { skor maksimal }} \times 100 \%
$$

Keterangan:

$\mathrm{P}=$ Persentase keterlaksanaan pembelajaran

(Arikunto, 2006:40)

Interpretasi skor

1) $21 \%$ - $40 \%$ dengan kriteria kurang

2) $41 \%-60 \%$ dengan kriteria cukup

3) $61 \%$ - $79 \%$ dengan kriteria baik

4) $80 \%$ - $100 \%$ dengan kriteria baik sekali

Persentase data angket siswa setelah menggunakan buku teks yang diperoleh dan dihitung secara deskriptif kuantitatif dengan persentase sebagai berikut:

$100 \%$

$$
\mathrm{P}(\%)=\frac{\text { jumlah yang menjawab "ya" atau "tidak" }}{\text { jumlah seluruh siswa }} \times
$$

Untuk menghitung rata-rata data angket siswa menggunakan rumus

$\mathrm{R}$

$$
=\frac{\text { Jumlah jawaban Ya }}{\text { Jumlah jawaban Ya }+ \text { Jumlah Jawaban Tidak }} \times 1
$$

Tabel 2. Kriteria Analisis Angket

\begin{tabular}{|c|c|}
\hline Skor & Kriteria Respon \\
\hline $21 \%-40 \%$ & Kurang \\
\hline $41 \%-60 \%$ & Cukup \\
\hline $61 \%-79 \%$ & Baik \\
\hline $80 \%-100 \%$ & Baik sekali \\
\hline
\end{tabular}

Persentase data angket guru setelah menggunakan buku teks yang diperoleh dan dihitung berdasarkan rumus rating scale berikut:

$$
\mathrm{P}(\%)=\frac{\text { Skor yang diperoleh }}{\text { Skor maksimal }} \times 100 \%
$$

(Riduwan, 2005:21)

Dalam penlitian ini, analisis hasil belajar siswa dihitung dengan rumus:

$$
\text { Nilai }=\frac{\text { skor perolehan }}{\text { skor maksimal }} \times 100
$$

Siswa dinyatakan tuntas belajar apabila telah mencapai nilai KKM yaitu $\geq 70$. Untuk mengetahui peningkatan hasil belajar siswa digunakan perhitungan persentase dengan rumus berikut:

$$
\text { PHB }=\frac{\text { skor post test }- \text { skor pre test }}{\text { skor maksimal }} \times 100 \%
$$

Pembelajaran secara klasikal dikatakan tuntas apabila $\geq 75 \%$ individu tuntas. Untuk menghitung ketuntasan belajar secara klasikal (PK) dihitung dengan menggunakan rumus:

$$
\mathrm{PK}=\frac{\text { Jumlah siswa yang tuntas }}{\text { Jumlah seluruh siswa }} \times 100 \%
$$

\section{HASIL DAN PEMBAHASAN}

Proses pengembangan buku teks dilakukan dengan menggunakan model 4D yang diadopsi dari Thiagarajan yang meliputi empat tahap, yaitu pendefinisian (define), perancangan (design), pengembangan (develop), dan penyebaran (dessimate). Namun penelitian ini berakhir pada tahap pengembangan karena mengingat keterbatasan waktu dan biaya, sehingga buku teks yang dikembangkan hanya digunakan pada sekolah yang digunakan sebagai tempat penelitian tanpa disebarkan pada sekolah lain.

Tahap pendefinisian bertujuan untuk menetapkan dan mendefinisikan kebutuhankebutuhan pembelajaran dengan menganalisis tujuan dan materi yang akan dikembangkan. Pada tahap pendefinisian ini peneliti telah melakukan beberapa tahapan, yaitu analisis awal akhir dengan tujuan menentukan masalah dasar yang dihadapi dalam pembelajaran bahasa Indonesia, analisis siswa dengan tujuan untuk menganalisis karakteristik siswa yang memiliki kemampuan, karakter dan perkembangan kognitif yang beragam, analisis konsep yang bertujuan mengidentifikasi bagianbagian utama materi yang akan diajarkan kemudian disusun secara sistematis dengan dirinci secara mendalam konsep yang relevan dan kurang relevan, analisis tugas bertujuan untuk mengidentifikasi tahap-tahap penyelesaian tugas agar tercapai kompetensi dasar, dan analisis tujuan pembelajaran yang menjadi dasar bagi pendidik dalam memilih metode pembelajaran, bahan ajar dan menyusun instrumen evaluasi.

Tahap perancangan bertujuan untuk mendapatkan draf awal atau draf I buku teks yang dikembangkan. Tahap ini sebagai acuan menyusun bahan buku teks berbasis karakter dengan menggunakan model pembelajaran example nonexample untuk kelas VI SD. Pada tahap perancangan, kegiatan yang dilakukan yaitu penulisan dan penyusunan buku teks draf I dan validasi draf I.

Hasil validasi komponen kelayakan materi memperoleh skor 45 dengan persentase 93,8\% dan dikatakan sangat layak digunakan dengan sedikit 
revisi. Komponen kelayakan penyajian memperoleh skor 37 dengan persentase 92,5\% dan dikatakan sangat layak digunakan dengan sedikit revisi. Komponen kelayakan penyajian memperoleh skor 26 dengan persentase $92,9 \%$ dan dikatakan sangat layak digunakan dengan sedikit revisi. Komponen kelayakan kegrafikaan memperoleh skor 40 dengan persentase $83,3 \%$ dan dikatakan sangat layak digunakan dengan sedikit revisi.

Tahap pengembangan adalah kelanjutan dari tahap perancangan yang menghasilkan buku teks bahasa Indonesia. Pada tahap ini, beberapa hal yang dapat dilakukan yaitu: revisi hasil validasi draf I, validasi buku teks draf II, revisi hasil validasi draf II, uji coba terbatas dan uji coba luas.

Kualitas buku teks bahasa Indonesia dinilai berdasarkan penilaian validator dan penggunaannya di dalam kelas. Penilaian validator dilihat dari aspek materi, bahasa, penyajian dan kegrafikaan. Pada kualitas penggunaannya dinilai dari aktivitas guru dan siswa, respons guru dan siswa, serta hasil belajar siswa. Uji kelayakan buku teks dilakukan pada uji coba terbatas dan uji coba luas.

Uji coba terbatas merupakan uji coba draf III buku teks pada siswa sekolah dasar. Uji coba terbatas diujicobakan pada siswa kelas VIB SDN Ketintang 1/409 Surabaya. Jumlah responden yaitu 13 dengan rincian 12 siswa dan 1 guru. Uji coba ini dilaksanakan pada hari Senin tanggal 6 April 2015. Aktivitas guru memperoleh skor rata-rata 77 dengan persentase $91,7 \%$ dan termasuk dalam kriteria baik sekali. Respons guru memperoleh skor 31 dengan persentase $86,1 \%$. Aktivitas siswa memperoleh skor 12 dengan persentase $75 \%$ dan termasuk kriteria baik. Respon siswa mendapat skor rata-rta 85 dengan kriteria sangat layak. Hasil belajar untuk ketuntasan klasikal hasil pre-test yaitu 66,7 \%. Sedangkan ketuntasan klasikal hasil post-test yaitu 91,7\%. Dari hasil ketuntasan klasikal pre-test dan post-test mengalami peningkatan sebesar $25 \%$ Berdasarkan nilai standar ketuntasan minimal yang diterapkan, maka hasil post-test dinyatakan tuntas.

Uji coba luas dilaksanakan di 2 kelas yaitu kelas VI A dan VI C di SDN Ketintang 1/409 Surabaya. Pelaksanaan uji coba luas di 2 kelas dilakukan untuk mengetahui keefektifan buku teks yang dikembangkan. Buku teks diujicobakan pada 64 responden, dengan rincian 62 siswa dan 2 guru. Penilaian dalam uji coba luas meliputi aktivitas guru dan siswa, respons guru dan siswa serta hasil belajar siswa.

Aktivitas guru kelas VIA memperoleh skor rata-rata 73,5 dengan persentase $87,5 \%$ dan termasuk dalam kriteria baik sekali. Sedangkan aktivitas guru kelas VIC memperoleh skor rata-rata 80,5 dengan persentase 95,8\% dan termasuk dalam kriteria baik sekali. Respons guru kelas VIA terhadap draf buku teks memperoleh skor 31 dengan persentase $86,1 \%$. Respon guru kelas VIC terhadap draf buku teks memperoleh skor 33 dengan persentase $97,1 \%$.

Aktivitas siswa kelas VIA memperoleh skor rata-rata 13,5 dengan persentase $84,4 \%$ dan termasuk dalam kriteria baik sekali. Aktivitas siswa kelas VIC memperoleh skor rata-rata 13 dengan persentase $81,3 \%$ dan termasuk dalam kriteria baik sekali. Respon siswa kelas VIA diperoleh hasil ratarata sebesar 90,7 dengan kriteria sangat layak digunakan. Respon siswa kelas VIC diperoleh hasil rata-rata sebesar 90,3 dengan kriteria sangat layak digunakan. Ketuntasan klasikal di kelas VIA dari hasil pre-test yaitu $56,7 \%$. Sedangkan ketuntasan klasikal hasil post-test yaitu $83,3 \%$. Dari hasil ketuntasan klasikal pre-test dan post-test mengalami peningkatan sebesar 26,6\%. Berdasarkan nilai standar ketuntasan minimal yang diterapkan, maka hasil post-test dinyatakan tuntas. Ketuntasan klasikal di kelas VIC dari hasil pre-test yaitu 66,7 \%. Sedangkan ketuntasan klasikal hasil post-test yaitu 86,7\%. Dari hasil ketuntasan klasikal pre-test dan post-test mengalami peningkatan sebesar $20 \%$. Berdasarkan nilai standar ketuntasan minimal yang diterapkan, maka hasil post-test dinyatakan tuntas.

Perancangan dan pembuatan buku teks tidaklah mudah. Hal ini harus dianalisis berdasarkan kebutuhan buku teks. Langkah awal yang dilakukan dalam pembuatan buku teks yaitu menganalisis kurikulum, menganalisis sumber belajar, dan menganalisis karakter siswa.

Menganalisis kurikulum tertuju pada kompetensi inti dan kompetensi dasar yang akan dikembangkan. Analisis sumber belajar yaitu dari hasil perolehan informasi dengan materi pokok yang akan dijabarkan. Analisis karakteristik siswa bertujuan untuk mengetahui kondisi dan perkembangan siswa.

Setelah pemetaan buku teks siap, maka penyusunan buku dimulai baik pemilihan sampelsampel bahasa, ilustrasi dan warna. Hal ini sesuai dengan pendapat Parera (dalam Yulianto, 2008:8), bahwa pemilihan sampel-sampel bahasa dalam pembelajaran harus diperhatikan, antara lain sampel sesuai dengan proses belajar bahasa, perkembangan belajar bahasa siswa, pengalaman siswa, dan bersifat kontekstual. 
Karakter yang terdapat pada buku teks antara lain, peduli lingkungan, toleransi, rasa ingin tahu, komunikatif, dan tanggung jawab. Hal ini sesuai dengan Kementerian Pendidikan Nasional Badan Penelitian dan Pengembangan Pusat Kurikulum (dalam Samani dan Hariyanto, 2012:60) bahwa ada18 nilai dalam pendidikan karakter yaitu sebagai berikut: religius, jujur, toleransi, disiplin, kerja keras, kreatif, mandiri, demokratis, rasa ingin tahu, semangat kebangsaan, cinta tanah air, menghargai komunikasi, bersahabat/komunikatif, cinta damai, gemar membaca, peduli lingkungan, peduli sosial, dan tanggung jawab.

Penyusunan buku teks ini mengikuti saran Fitrah (2013) dan Ambarwati (2014), agar buku pelajaran siswa sebaiknya mengikuti pedoman penyusunan buku pelajaran menurut BSNP. Saran disampaikan oleh Muslich (2010:34) yaitu cara-cara memilih buku teks yang tepat bagi anak kita sebagai penunjang proses pembelajaran di sekolah. Permasalahan itu muncul tatkala buku teks yang ada mempunyai variasi yang bermacam-macam, baik dari segi kualitas maupun kuantitasnya. Disarankan agar buku teks yang ditulis dapat memecahkan permasalahan dan mengupas tuntas permasalahan siswa. Bahkan Mintowati (2008) menyarankan,untuk memilih materi yang kontekstual dan disampaikan berdasarkan topik yang saling terkait.

Berdasarkan penelitian yang telah dilakukan, buku teks bahasa Inodenesia dapat membantu guru dalam melaksanakan pembelajaran. Berdasarkan hasil pengamatan yang dilakukan pada tahap uji coba terbatas dan uji coba luas siswa sangat antusias dalam mengikuti pembelajaran, dibandingkan dengan kegiatan sebelum menggunakan buku teks bahasa Indonesia yang diterapkan.

Sebelum dilakukannya uji coba terbatas, buku teks telah melewati beberapa revisi dari validator dan telah dinyatakan kelayakannya sehingga dapat digunakan dalam pembelajaran. Gooch (2012) menjelaskan bahwa tahap uji coba bertujuan untuk mengumpulkan informasi tambahan yang berkaitan dengan produk yang dikembangkan melalui evaluasi dari ahli maupun evaluasi lapangan. Setelah dilakukan validasi, buku teks dapat digunakan pada tahap uji coba.

Selama proses pembelajaran pada tahap uji coba terbatas dan uji coba luas menunjukkan bahwa dengan menggunakan buku teks bahasa Indonesia dapat membantu guru dalam pembelajaran bahasa Indonesia.
Selain itu buku teks bahasa Indonesia dapat meningkatkan motivasi siswa terhadap pelajaran bahasa Indonesia. Selama proses pembelajaran berlangsung memberikan dampak positif terhadap keaktifan dan hasil belajar siswa. Keaktifan siswa terlihat pada antusias siswa terhadap pembelajaran. Sedangkan hasil belajar yang diperoleh mengalami peningkatan. Peningkatan hasil belajar dilihat dari hasil pre-test dan post-tes.

\section{SIMPULAN}

Simpulan yang dipaparkan ini berdasarkan hasil penelitian yang disesuaikan dengan rumusan masalah. Dari penelitian ini, maka dapat disimpulkan bahwa proses pengembangan produk melalui tiga tahapan yaitu tahap pendefinisian, perancangan, dan pengembangan. Tahap pendefinisian meliputi lima langkah pokok yang harus dilakukan, yaitu analisis awal akhir, analisis siswa, analisis konsep, analisis tugas, dan analisis tujuan pembelajaran. Tahap perancangan meliputi penulisan dan penyusunan buku teks dan validasi draf I. Tahap pengembangan meliputi revisi hasil validasi draf I, validasi buku teks draf II, revisi hasil validasi draf II, uji coba terbatas dan uji coba luas.

Kualitas buku teks dinilai dari segi produk dan dari segi penggunaannya di kelas. Dari segi produk, buku teks dinilai dari komponen materi, penyajian, bahasa, dan kegrafikaan. Komponen materi mendapat skor 47 dengan persentase 97,9\%. Komponen penyajian mendapat skor 40 dengan persentase $100 \%$. Komponen bahasa mendapat skor 27 dengan persentase 96,4\%. Komponen kegrafikaan mendapat skor 45 dengan persentase 93,8\%. Dari hasil penilaian validator diperoleh persentase rata-rata $96,9 \%$, dengan kategori sangat layak.

Kualitas buku teks dari segi penggunaan di kelas ditentukan oleh aktivitas guru, respon guru, aktivitas siswa, respon siswa dan hasil belajar siswa. Dari hasil uji coba terbatas ativitas guru mendapat persentase $91,7 \%$. Respon guru mendapat persentase $86,1 \%$. Aktivitas siswa mendapat persentase $75 \%$. Respon siswa mendapat hasil rata-rata 85 . Hasil belajar siswa dari hasil pre-test dan post-test mengalami peningkatan sebesar 15,2. Dari hasil ketuntasan klasikal pre-test dan post-test mengalami peningkatan sebesar $25 \%$.

Hasil uji coba luas yaitu aktivitas guru di kelas VIA mendapat persentase $87,5 \%$, sedangkan di kelas VIC mendapat persentase $95,8 \%$. Respons guru kelas VIA mendapat persentase $86,1 \%$, sedangkan di kelas VIC mendapat persentase $97,1 \%$. 
Aktivitas siswa di kelas VIA mendapat persentase $84,4 \%$, sedangkan di kelas VIC mendapat persentase $81,3 \%$. Respons siswa di kelas VIA mendapat hasil rata-rata 90,7, sedangkan di kelas VIC mendapat hasil rata-rata 90,3. Hasil belajar di kelas VIA dari hasil pre-test dan post-test mengalami peningkatan sebesar 9,5. Dari hasil ketuntasan klasikal pre-test dan post-test mengalami peningkatan sebesar $26,6 \%$. Hasil belajar di kelas VIC dari hasil pre-test dan post-test mengalami peningkatan sebesar 8,6. Ketuntasan klasikal hasil pre-test yaitu 66,7\%. Dari hasil ketuntasan klasikal pre-test dan post-test mengalami peningkatan sebesar $25 \%$.

\section{DAFTAR PUSTAKA}

Ambarwati, Arista. (2014). Pengembangan Bahan Ajar Berpendakatan Savi pada materi menulis laporan hasil diskusi untuk kelas XII SMA. (Tesis magister pendidikan tidak dipublikasikan). Universitas Negeri Surabaya

Aqib, Zainal. (2013). Model-Model,Media, dan Strategi Pembelajaran Kontekstual (Inovatif). Bandung: Yrama Widya

Arikunto, Suharsimi. (2006). Prosedur Penelitian: Suatu Pendekatan Praktik. Jakarta: PT Rineka Cipta

Fitrah, Ummi. (2013). Pengembangan Buku Teks Bahasa Indonesia Tematik Integratif Berbasis Budaya Madura dengan Menggunakan Model Pembelajaran Kooperatif untuk Kelas IV Sekolah Dasar (Tesis magister pendidikan tidak dipublikasikan). Universitas Negeri Surabaya

Gooch, Deanna L. (2012). Research, Development, And Validation of a School Leader's Resource Guide For The Facilitation of Social Media Use by School Staff. Kansas: Kansas State University

Louis, Cohen, Lawrence, Manion and keith Morrison. (2011). Research Methods in Education. New York: Ashford Colour Press.

Mintowati, M. (2008). Tuturan Penyandang Autis (Kajian Tindak Tutur, Prinsip Kooperatif, dan Strategis. (Disertasi doktor pendidikan tidak dipublikasikan). Universitas Negeri Surabaya
Muslich, Masnur. (2010). Text Book Writing: DasarDasar Pemahaman, Penulisan, dan Pemakaian Buku Teks. Jogjakarta: Ar-Ruzz Media

Riduwan. (2005). Skala Pengukuran VariabelVariabel Penelitian. Bandung: Alfabeta

Samani, Muchlas dan Hariyanto. (2012). Konsep dan Model Pendidikan Karakter. Bandung: PT Remaja Rosdakarya

Sugiyono. (2008). Metode Penelitian Pendidikan Pendekatan Kuantitatif, Kualitatif, dan $R \& D$. Bandung: Alfabeta

(2013). Metode Penelitian Kombinasi

(Mixed Methods). Bandung: Alfabeta

Sukmadinata, Nana Syaodih. (2005). Metode Penelitian Pendidikan. Bandung: Remaja Rosdakarya

Suyono \& Hariyanto. (2011). Belajar dan Pembelajaran: Teori dan Konsep. Bandung: Remaja Rosdakarya

Trianto. (2007). Model Pembelajaran Terpadu dalam Teori dan Praktek. Jakarta: Prestasi Pustaka Publisher.

Ulum, Wisda Miftakhul. (2013). Pengembangan Buku Teks Membaca Intensif KelasVI Berbasis Karakter di Sekolah Dasar (Tesis magister pendidikan tidak dipublikasikan). Universitas Negeri Malang.

Yulianto, Bambang. 2008. Aspek Kebahasaan dan Pembelajarannya. Surabaya: Unesa University Press

http://luk.staff.ugm.ac.id/atur/Permendiknas22008Buku.pdf diakses pada tanggal 27 Agustus 2014

http://kemenag.go.id/file/dokumen/PP1905.pdf diakses pada tanggal 27 Agustus 2014 